\title{
PERSAINGAN INDUSTRI RITEL DI INDONESIA DENGAN MODEL "LIMA KEKUATAN PESAING M. PORTER"
}

\author{
Mukhammad Kholid Mawardi \\ Fakultas Ilmu Administrasi Universitas Brawijaya Malang
}

\begin{abstract}
The most disruptive competition industry in Indonesian business is retail industry, having significant role in value chain management of product distribution from producers to consumers. To asess retail industry competition in Indonesia writer use the five force model introduced by Michael Porter. This model is the implementation of S-C-P (Structure-Conduct-Performance) paradigm in industries asessment. This articles concluded that retail industry in Indonesia is attractive and longlasting industry
\end{abstract}

Keywords : retail industry, five force model

Tidak ada kata yang paling sering diungkap dalam kajian bisnis dalam konteks kekinian selain kata perubahan (change), mulai dari perubahan lingkungan, perubahan budaya organisasi, perubahan struktur organisasi maupun perubahan selera pasar. Perubahan merupakan fenomena berparadigma ganda, satu sisi akan menjadi sebuah ancaman dan bahkan akan mampu meruntuhkan dominasi sebuah korporasi disisi lain perubahan mampu menjadi kekuatan pendorong dinamisnya sebuah korporasi yang mengarah pada inovasi karena kemampuannya beradaptasi terhardap perubahan yang terjadi. Perubahan akan berkontribusi bagi perusahaan ketika perusahaan memiliki mekanisme yang mampu mempertankan kesadaran dan sekaligus mengelola perubahan, baik yang berasal dari dalam maupun luar perusahaan.

Terkait dengan perubahan di bidang bisnis, terdapat berbagai pendapat dan kajian mengenai hal tersebut, antara lain diungkapkan Grimm (2006) yang menggunakan istilah Disruptive Competition untuk mengeksplorasi dinamika lingkungan bisnis, dengan ciri-ciri waktu respon antar pelaku yang semakin cepat, meningkatnya intensitas aksi-reaksi dengan bentuk potongan harga, munculnya produk baru dan meningkatnya paten dan dicirikan dengan lingkungan dengan jumlah pesaing yang meningkat dan banyaknya kegagalan yang 
dialami oleh pelaku bisnis. Pendekatan lain dalam memahami perubahan lingkungan juga diungkapkan oleh Ansoff dan Sullivan dalam Hutabarat (2006) dengan pendekatan turbulensi lingkungan, yang mengungkapkan bahwa lingkungan yang dihadapi perusahaan telah berubah dan mengalami turbulensi (pergolakan) yang semakin cepat dan untuk berhasil dalam lingkungan diperlukan agresivitas strategi dan respons kapabilitas manajemen.

Perspektif perubahan lingkungan yang telah disebutkan sebelumnya relevan untuk digunakan sebagai dasar memahami industri ritel di Indonesia yang mengalami perubahan dengan cepat menuju kemapanan industri. Mengutip pendapat Lim dua belas tahun lalu (1996) yang telah memprediksi bahwa Asia Tenggara dan Cina yang seluas 3,360 juta hektar akan menjadi penghuni 1,76 milyar penduduk dengan berbagai budaya dan tingkat sosial budaya, konsekenasi hal tersebut akan menciptakan konsumen baru pada industri ritel di China sebesar 140 juta, 35 juta di Indonesia, 8 juta di Thailand , 3 juta di Malaysia dan 1 juta di Singapura dalam satu dekade. Sementara itu wilayah yang perekonomiannya telah mengalami kemajuan terlebih dahulu seperti Hongkong dan Taiwan, industri ritelnya telah mapan seperti di Amerika Serikat, Canada dan Eropa sehingga pelaku retail global memfokuskan pasar baru.

Untuk lebih memahami karakteristik industri ritel di Indonesia, model lima kekuatan persaingan yang digagas Michael E.Porter, profesor strategi dari Harvard Business School akan mempermudah kita dalam memetakan persaingan industri ritel. Konsep lima kekuatan persaingan mendorong konsep lingkungan industri ke dalam pemikiran strategi dan perencanaan usaha. Aspek analisis dari sisi lingkungan industri atau persaingan bisnis, dikembangkan oleh Porter (1997) melalui konsep Competitive Strategy yang menganalisis persaingan bisnis berdasarkan lima kekuatan bersaing atau Five Competitive Forces (Umar, 2002; Hitt, et al., 2001 Pearce dan Robinson, 1997; Wahyudi, 1996).

\section{MODEL PERSAINGAN}

Dalam literatur ekonomi terdapat perspektif yang berbeda-beda dalam melihat persaingan dalam sebuah industri, yang paling populer adalah model lima kekuatan persaingan oleh Michael Porter yang merupakan derivasi dari model kerangka fikir dari model ekonomi Industrial Organization (IO) yaitu Structure-Condust-Performance (SCP) (Grimm, 2006). Lebih jauh Grimm mendefinisikan (2006) kajian ekonomi Organisasi industrial sebagai kajian yang mempelajari sisi penawaran dari sebuah perekonomian khusunya di pasar, dan secara 
konseptual model SCP berargumen bahwa struktur pasar yang sangat terkonsentrasi dan didominasi oleh sedikit pemain besar akan mendorong rendahnya persaingan, harga dan keuntungan yang eksesif (ekstrim) atau dengan kata lain struktur industri yang terdiri dari banyak perusahaan dengan skala kecil akan menghasilkan tingkat persaingan yang tinggi dan rendahnya harga dan keuntungan.

Dengan bahasa lain Scherer \& Ross (1990) menjelaskan atribut yang menentukan kinerja pasar dalam kacamata Industrial Organization (IO) ditentukan oleh konsep Structure Conduct Performance (SCP) yang mengungkapkan bahwa kinerja pasar adalah merupakan fungsi struktur dan perilaku pasar. Dia berargumen bahwa struktur pasar yang berbeda akan menyebabkan perilaku pemain yang berbeda dan pada akhirnya menghasilkan dampak pasar (kinerja) yang berbeda. Pasar ditentukan oleh karakteristik struktur pasar seperti konsentrasi pemasok secara horisontal maupun vertikal atau tingkat diferensiasi produk (Wirth \& Bloch, 1995). Perilaku pasar mengacu pada perilaku perusahaan di pasar misalnya, skema harga, startegi produk dan pemasaran serta riset dan pengembangan.

Apabila studi organisasi industrial berfokus pada kajian hubungan antara struktur industri, perilaku dan kinerja, sedangkan Michael Porter merupakan pioner yang mengaplikasikan konsep IO dalam formulasi strategi. Secara lebih spesifik, dia melihat keterkaitan paradigma struktur-perilaku-kinerja sebagai model sistematis bagi manajer untuk menilai persaingan dan strategi untuk meningkatkan keuntungan (Grimm, 2006). Sebagian besar praktisi dan peneliti manajemen strategik mengenal ide ekonomi Industrial Organization (IO) dari buku karangan Micahel Porter strategi bersaing tahun 1980, khususnya model lima kekuatan persaingan. Model tersebut merupakan ikhtisar Porter untuk mengarahkan banyak riset dibidang ekonomi yang berbasis pada IO ke arah konsep manajemen stratejik, sehingga struktur industri diyakini sebagai penentu keunggulan kompetitif.

\section{Lima Kekuatan Penentu Persaingan}

Model lima kekuatan dalam persaingan oleh Porter sebagai penggagas Competitive Strategy, ditunjukkan pada gambar 1 berikut:

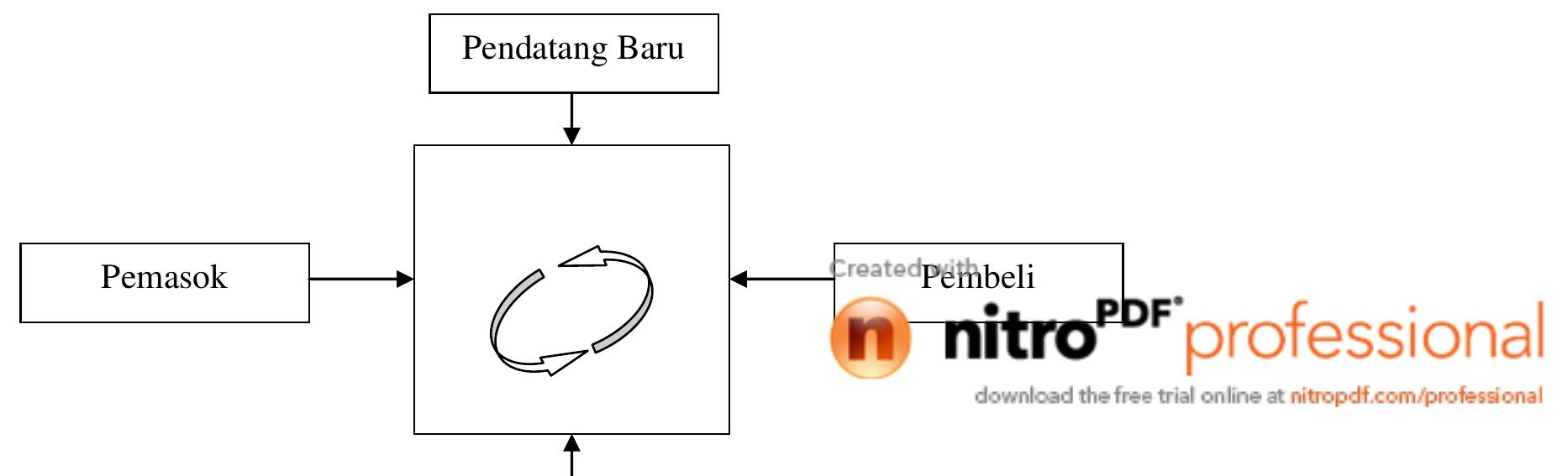


Secara lengkap kelima aspek atau variabel yang membentuk model strategi bersaing dalam industri tersebut dijelaskan pada paparan berikut ini,

\section{Ancaman Pendatang Baru}

Banyaknya pendatang baru potensial yang tertarik masuk ke dalam industri (Wahyudi, 1996), akan menimbulkan sejumlah implikasi bagi perusahaan yang sudah ada dan diterima oleh pasar. Pendatang baru dalam industri biasanya membawa kapasitas baru, keinginan untuk merebut dan mendapatkan pangsa pasar, serta merebut sumber daya produksi penting lainnya yang jumlahnya terbatas. Kondisi demikian akan menimbulkan ancaman bagi perusahaan yang sudah ada, di mana pendatang baru akan masuk ke dalam persaingan industri.

Namun terdapat sejumlah faktor penghambat atau penghalang bagi pendatang baru untuk masuk ke dalam suatu persaingan industri/pasar yang sering disebut dengan barriers to entry. Faktor-faktor penghambat bagi pendatang baru untuk masuk ke dalam persaingan industri/pasar menurut Porter, (Umar, 2002 ;Wheelen dan Hunger, 2001; Pearce dan Robinson, 1997; dan Wahyudi, 1996) adalah :

(1) Skala Ekonomi

(2) Diferensiasi Produk

(3) Kebutuhan Modal

(4) Biaya Peralihan

(5) Kebijakan Pemerintah

\section{Kekuatan Tawar Menawar Pembeli}

Para pembeli atau pelanggan baik secara individu atau organisasi/lembaga dengan kekuatan yang mereka miliki mempunyai kemampuan mempengaruhi industri untuk 
menekan dan menurunkan harga produk yang lebih murah, menuntut peningkatan kualitas yang lebih baik, service atau layanan yang lebih berkualitas, serta membandingkan perusahaan dengan para kompetitornya melalui kekuatan yang mereka miliki.

Dengan demikian, para pembeli atau pelanggan akan mem punyai posisi atau kekuatan tawar menawar yang tinggi, bila kondisi berikut ini terpenuhi.

(1) Pembeli membeli sebagian besar dari penjualan produk perusahaan atau pembeli membeli dalam jumlah banyak.

(2) Pembeli memiliki kemampuan potensial untuk melakukan integrasi ke belakang dengan menghasilkan produknya sendiri.

(3) Sifat produk yang akan dibeli dari industri tidak mempunyai perbedaan yang signifikan (undifferentiated) dengan produk pesaing/pemasok lain.

(4) Pembeli dapat beralih atau berpindah ke produk lain (switching cost) dengan biaya yang cukup rendah.

(5) Pembeli memandang produk perusahaan tidak terlalu penting bagi pembeli, sehingga akan dengan mudah untuk mencari barang penggantinya (substitusi).

\section{Kekuatan Tawar Menawar Pemasok}

Pemasok dapat memanfaatkan kekuatan tawar menawar atas industri dengan menaikkan harga atau menurunkan kualitas produk yang dipasok/dijual bila suatu industri tidak menepati kesepakatan yang dilakukan. Pemasok yang kuat akan dapat menekan kemampulabaan suatu industri dengan cara menaikkan harga dari suatu produk yang dipasok. Kondisi seperti ini merupakan cara-cara potensial yang dapat dilakukan oleh pemasok untuk menunjukkan pengaruhnya terhadap perusahaan yang bersaing dalam industri. Apabila pemasok mampu mengendalikan perusahaan industri dengan menyediakan input yang diperlukan perusahaan industri, sedang perusahaan industri tidak mempunyai kemampuan untuk mengendalikan pemasok, maka posisi tawar perusahaan industri menjadi lemah dan sebaliknya posisi tawar menawar pemasok menjadi kuat.

Dengan demikian, para pemasok akan mempunyai kekuatan tawar menawar yang tinggi, apabila beberapa kondisi berikut ini terpenuhi:

(1) Pemasok hanya didominasi oleh sedikit perusahaan pemasok, namun menjual ke banyak perusahaan industri dan lebih terkonsentrasi pada industri yang dilayani. 
(2) Produk pemasok bersifat unik atau setidak-tidaknya terdiferensiasi. Hal ini karena spesifikasi produk yang diperlukan oleh perusahaan pembeli terikat pada pemasok yang bersangkutan.

(3) Perusahaan industri bukanlah pelanggan/pembeli penting bagi pemasok, sebaliknya produk pemasok merupakan input paling penting bagi kebanyakan perusahaan industri.

(4) Perusahaan pemasok memiliki kemampuan untuk melakukan integrasi ke depan (forward integrated) dan mengelola produk yang hasilnya sama dengan produk perusahaan industri serta bersaing secara langsung dengan mendirikan gerai-gerai ritel untuk melayani pembeli atau pelanggannya. Hal ini berarti memaksa pembeli industri untuk dapat menerima syarat-syarat pembelian yang telah ditetapkan oleh pemasok.

(5) Perusahaan industri pembeli hanya membeli dalam jumlah kecil dari perusahaan pemasok.

(6) Tidak tersedia produk pengganti yang memuaskan bagi perusahaan dalam industri tersebut.

4. Persaingan di antara Perusahaan.

Sebagian besar perusahaan dalam suatu industri satu sama lainnya saling tergantung, oleh karena itu tindakan yang diambil biasanya merupakan tindakan kompetitif. Hal ini terjadi karena di antara perusahaan berupaya merebut posisi bersaing melalui persaingan harga, perang iklan, maupun bersaing melalui pengenalan produk baru. Kondisi persaingan yang demikian, akan dapat mempengaruhi kebijakan dan kinerja perusahaan. Menurut Porter (1997) tingkat persaingan di antara perusahaan dalam industri dipengaruhi oleh beberapa faktor, yaitu:

(1) Jumlah Pesaing.

(2) Tingkat Pertumbuhan Industri.

(3) Karakteristik Produk.

(4) Total Biaya Tetap.

(5) Kapasitas Produksi.

(6) Hambatan Keluar Tinggi.

5. Ancaman Produk Substitusi 
Perusahaan yang berada dalam suatu industri tertentu akan bersaing pula pada produk substitusi/pengganti. Produk substitusi adalah produk yang berada di luar industri tertentu yang mempunyai atau melakukan fungsi serupa dengan produk yang dihasilkan suatu industri. Secara umum produk substitusi merupakan ancaman bagi perusahaan industri, bilamana pelanggan dihadapkan pada biaya pemindahan (switching cost) yang lebih murah, namun dari sisi kualitas relatif sama dari produk suatu industri atau produk aslinya.

Produk substitusi/pengganti secara strategik layak diperhitungkan atau bahkan menjadi ancaman yang kuat bagi industri, bila:

(1) Kualitasnya relatif mampu menandingi kualitas produk industri.

(2) Produk substitusi/pengganti memberikan nilai manfaat yang relatif sama dengan produk industri.

(3) Produk substitusi/pengganti harganya cenderung menjadi semakin murah dibandingkan dengan produk yang dihasilkan oleh produk perusahaan industri.

(4) Produk substitusi/pengganti dihasilkan dalam skala besar dan sangat menguntungkan bagi perusahaan.

(5) Biaya peralihan (switching cost) tidak signifikan bagi konsumen bila berpindah ke produk substitusi.

(6) Pembeli atau pelanggan telah terbiasa dengan produk substitusi yang harganya lebih murah, namun manfaat dan kualitasnya relatif sama.

\section{INDUSTRI RITEL DI INDONESIA}

Perkembangan industri ritel di Indonesia dipelopori oleh pemerintah dengan didirikannya Sarinah sebagai pusat perbelanjaan modern pertama di Jakarta. Dalam kurun waktu yang tidak terlalu lama bermunculan ritel-ritel baru dan puncaknya pada tahun 1997 pemerintah melalui surat Keputusan Menteri Keuangan nomor : 455/KMK/01 tahun 1997 memberikan ijin masuk bagi ritel-ritel asing seperti Carefour dan Continent.

Indonesia sebagai negara dengan jumlah penduduk besar menjadi lahan menguntungkan bagi investor di sektor ritel. Kemudahan izin pendirian pasar modern juga berkontribusi pada pesatnya perkembangan pasar modern. Menurut survey yang dilakukan AC Nielson, tahun 2006 total pertumbuhan pasar modern di Indonesia sebesar 14,3\% dan toko modern mengalami pertumbuhan sebesar 23,8\% jauh lebih cepat dibandingkanpertumbuhan 
pasar tradisional yang hanya mencapai 9,6\%. Pada survey yang sama, diketahui tiga jenis ritel mencatat pertumbuhan yang cukup pesat, yaitu Hypermart sebesar 42,6\%, supermarket 6,4\% dan minimarket sebesar 34,2\% (Kompas, Sabtu 23 Juni 2007). Perumbuhan pasar modern disebabkan karena meningkatnya jumlah gerai ritel di Indonesia sebagai dampak adanya ekspansi toko-toko ritel di kota baik di Pulau Jawa maupun luar Pulau Jawa. Tercatat antara tahun 2003 hingga 2006 perkembangan jumlah gerai pengecer modern sebanyak 5.0001, 6.650, 7.7112 dan 8.891 unit (Warta Ekonomi, 08 th. XIX 16 April 2007)

\section{Analisis Persaingan Industri Ritel di Indonesia}

\section{Intensitas Persaingan diantara Pelaku Ritel di Indonesia}

Sebagian besar perusahaan dalam suatu industri satu sama lainnya saling tergantung, oleh karena itu tindakan yang diambil biasanya merupakan tindakan kompetitif. Hal ini terjadi karena di antara perusahaan berupaya merebut posisi bersaing melalui persaingan harga, perang iklan, maupun bersaing melalui pengenalan produk baru. Kondisi persaingan yang demikian, akan dapat mempengaruhi kebijakan dan kinerja perusahaan, dalam perspektif S-C$\mathrm{P}$, perilaku pasar para pemain dalam Industri dipengaruhi oleh struktur industri tersebut.

Untuk memahami persaingan industri ritel di Indonesia perlu kiranya merujuk pada kajian yang dilakukan Priyono dkk (2003) yang mengklsifikasi ritel menjadi empat yaitu (1) pengecer tradisional/pasar tradisional (2) grosir atau Hypermarket (3) pengecer besar dan (4) minimarket modern. Lebih lanjut dalam kajian yang dilakukan Centre Policy Analysis (2003) menyebutkan lima pemain besar pada Grosir. Hypermarket adalah Alfa, Makro, Carrefour, Goro dan Giant sedangkan dalam kelompok eceran skala besar dan menengah terdapat 20 pemain.

Pasar industri ritel di Indonesia adalah pasar persaingan sempurna yang sangat intensi dimana teradapat banyak pemain dan menyediakan produk/jasa yang relatif sempurna, karakteristik persaingan lainnya adalah tidak jelasnya batas kategori ritel itu sendiri sehingga tidak jarang ritel dalam skala besar berhadap-hadapan dengan ritel skala kecil atau bahkan dengan pengecer tradisional. Relevan dengan ungkapam Ma'ruf (2006) yang memodelkan persaingan ritel seperti nampak dalam gambar berikut :

Gambar 2

Persaingan antara Ritel

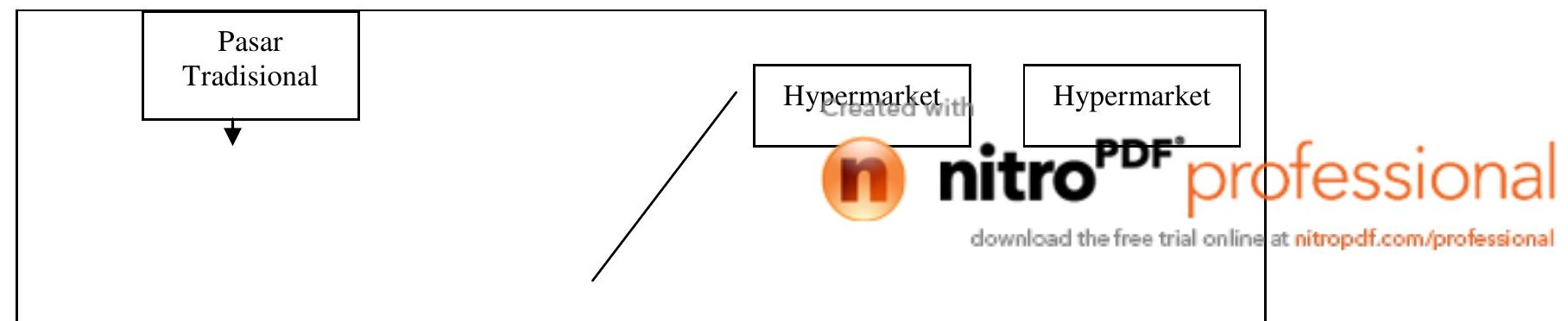




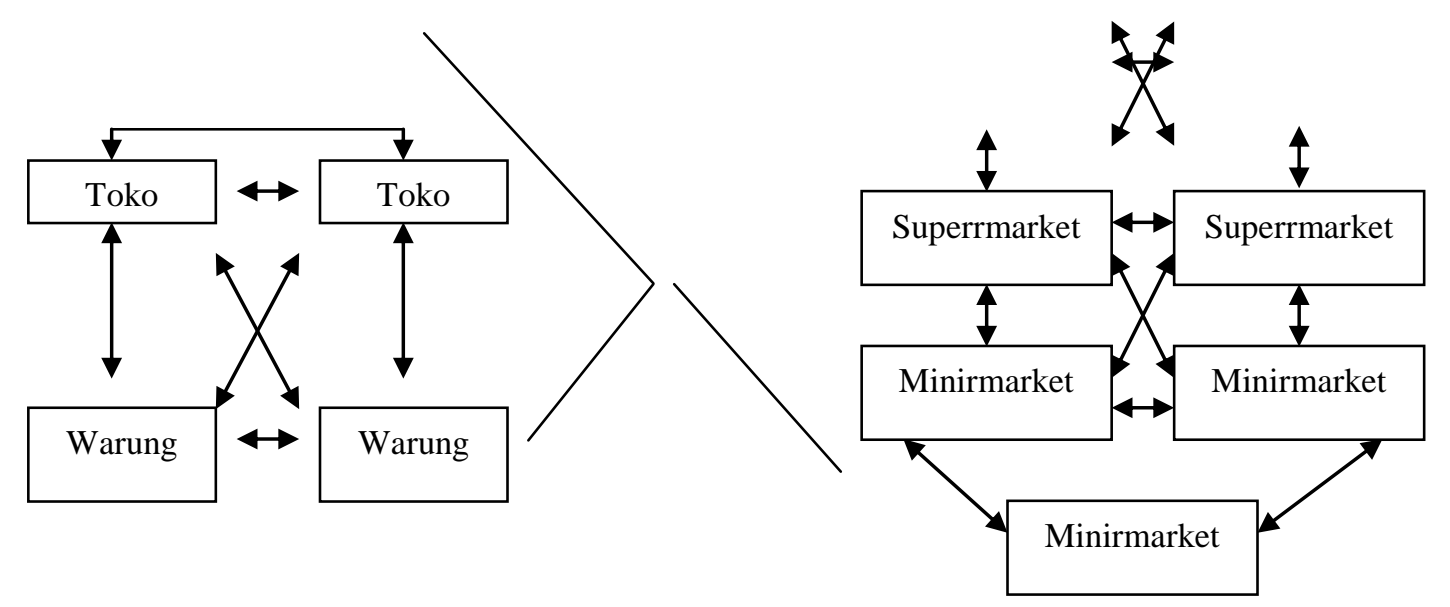

Sumber : Ma'ruf, 2006

Dari gambar 2, nampak bahwa persaingan tidak hanya terjadi pada satu kategori ritel tetapi juga terjadi antar kategori ritel bahkan antara pasar ritel modern dengan pasar tradisional. Kajian mengenai persaingan antara pasar ritel modern dengan pasar tradisional bisa dirujuk pada kajian oleh Sinaga (2006) dan Tambunan (2004) yang pada muaranya menjelaskan bahwa persaingan yang terjadi pada industri ritel merupakan persaingan yang intens dan melibatkan banyak pemain.

\section{Daya Tawar Konsumen}

Konsumen pada industri ritel memiliki daya tawar tinggi dengan berbagai argumen, antara lain: mayoritas konsumen pada industri ritel adalah konsumen individu sehingga mayoritas peritel membidik segmen individu dalam strategi pemasarannya karena ketergantungnnya dengan konsumen individual, karakteristik produk yang dijual tidak memiliki perbedaaan siginifikan dengan produk yang disediakan peritel lain sehingga konsumen dengan sangat mudah beralih atau berpindah kepada peritel lain karena hanya membutuhkan biaya (switching cost) rendah. Daya tawar konsumen yang tinggi mendorong peritel melakukan strategi promosi dan pricing yang intensif untuk memenangkan persaingan merebut konsumen sebanyak-banyaknya.

\section{Daya Tawar Pemasok}

Kondisi industri ritel mendorong peritel tumbuh menjadi kekuatan besar dengan market power yang mampu mendikte pemasok sehingga terjadi ketidakseimbangan daya tawar antara peritel dan pemasok. Potensi persaingan usaha tidak sehat dapat muncul dalam bentuk penyalahgunaan market power. Hal ini antara lain muncul dalam trading term antara peritel dan pemasok, ketidakadilan hubungan pemasok dan peritel diwujudkan dalam perbedaan besaran 
biaya syarat perdagangan satu pemasok dengan lainnya. Pemasok terutama yang produknya banyak diminati konsumen mendapat perlakuan lebih lunak dari peritel.

Kondisi tersebut menyebabkan lemahnya posisi pemasok dihadapan peritel sehingga penentu akhir dalam penentu pasokan adalah peritel dan peritel telah mampu menjadi bagian terpenting dalam majamenen rantai pasokan (suplly chain management) barang hingga ke tangan konsumen akhir.

\section{Ancaman Pendatang Baru}

Meskipun industri ritel merupakan industri yang menarik karena menawarkan tingkat keuntungan yang tinggi tetapi terdapat sejumlah faktor penghambat atau penghalang (barriers to entry) bagi pendatang baru untuk masuk ke dalam persaingan industri ritel di Indonesia. Faktor-faktor penghambat utama bagi pendatang baru untuk masuk ke dalam persaingan industri ritel meliputi : (1) Kebutuhan Modal: dibutuhkan modal yang besar untuk mampu mendirikan gerai ritel di tempat strategis dengan ketersediaan produk yang lengkap disisi lain muncul kekuatan pemain ritel nasional maupun global dengan modal yang besar seperti : Carrefour, 7 Eleven, Wall Mart, Tesco, Hypermart, Giant, Sogo, Seibu dan sebagainya, juga akan menambah halangan bagi pemain ritel (khususnya pemain lokal) untuk masuk dalam persaingan. Entry barrier yang pertama mendorong munculnya entry barrier kedua, yaitu (2) Skala Ekonomi, pemain -pemain ritel besar akan memaksa skala ekonomis industri ritel menjadi sangat efisien dan menekan persaingan harga pada level terendah. Kekuatan ritel untuk mengakses produk sekaligus menekan produsen dalam standarisasi kualitas dan harga, ditambah penerapan konsep supply chain management pada rantai pasokan akan menyebabkan industri ini semakin efisien dan kompetitif. (3) Peraturan pemerintah dalam mengatur industri ritel sangat kondusif terlihat dari keluarnya Keputusan Presiden No 96/2000 No 118/2000 yang mencabut ritel dari negative list investasi maupun Peraturan Presiden Republik Indonesia nomor 77 tahun 2007 tentang daftar bidang usaha yang tertutup dan bidang usaha yang terbuka dengan persyaratan di bidang penanaman modal yang membolehkan modal asing dalam industri ritel. Terkait dengan pengaturan persaingan industri ritel terdapat Komisi Pemantau Persaingan Usaha (KPPU) yang bertugas untuk melakukan penegakan hukum persaingan dan memberikan saran pertimbangan kepada Pemerintah (UU No 5 Tahun 1999),

bentuk keterlibatan KPPU dalam sektor ritel adalah kasus Indomaret Putusan KPPU No.03/KPPU-L/I/2000 dan kasus Carrefour Putusan KPPU No. 02/KPPU - L/2005 .

\section{Created with}


Perarutan pemerintah yang memberatkan peritel hanya Peraturan daerah yang berbeda antara satu daerah yang satu dengan daerah lainnya tentang izin, zonasi, pengaturan waktu buka, kemitraan maupun kewajiban menjual produk dalam negeri

\section{Ancaman Produk/Jasa Subsitusi}

Industri ritel terkait dengan perilaku konsumen dalam berbelanja, sehingga perubahan perilaku masyarakat berbelanja dari pasar tradisional ke ritel modern merupakan trend yang sedang terjadi yang direspon dan dipelihara oleh peritel. Pada sebagian kecil segmen masyarakat yang memiliki keterbatasan waktu dalam berbelanja dan memiliki kesadaran yang tinggi terhadap perkembangan teknologi informasi mulai menggunakan metode alternatif dalam berbelanja yaitu berbelanja melalui telphon (tele-shoping) atau berbelanja melalui internet (e-shoping). Fakta tersebut direspon oleh sebagaian produsen/penyedia produk dengan menawarkan metode tersebut namun dalam jumlah yang relatif kecil dan untuk produk tertentu. Produsen tertentu juga mendistribusikan produk melalui jalur multi level marketing dan tidak menggunakan ritel sebagai tempat penjualannya dalam rangka melakukan efisiensi biaya penjualan.

Kedua model berbelanja tersebut merupakan ancaman produk/jasa substitusi bagi peritel namun perlu digarisbawahi bahwa model berbelanja tersebut sangat terkait dengan perubahan budaya berbalanja dikalangan masyarakat Indonesia, disamping tujuan konsumen datang ke pasar modern dimana terletak ritel-ritel besar bukan hanya berbelanja tepai juga tujuan rekreatif sehingga ancaman model berbelanja seperti diungkap sebelumnya bukanlah merupakan ancaman yang nyata.

\section{KESIMPULAN}

1. Industri ritel merupakan industri yang paling cepat mengalami perkembangan baik secara nasional maupun secara global, sehingga tidak ada pilihan bagi peritel untuk melakukan perubahan-perubahan strategi guna merespon perkembangan tersebut.

2. Terdapat banyak konsep yang berpendapat tentang penentu kinerja sebuah industri, konsep Struktur-Perilaku-Kinerja (Structure -Conduct-Performance) merupakan konsep 
yang sering dianut dan telah diterjemahkan dalam model lima kekuatan persaingan oleh Michael Portet untuk mengukur persaingan dalam sebuah industri.

3. Dengan model lima kekuatan persaingan, dimana diketahui intensitas persaingan, daya tawar konsumen, daya tawar pemasok, ancaman pendatang baru dan ancaman produk pengganti industri ritel di Indonesia dapat disimpulkan sebagai industri yang menarik dan akan bertahan dalam jangka waktu yang panjang.

\section{DAFTAR PUSTAKA}

Grim . 2006. Strategy As Action. Oxford University Press

Hitt. Ireland and Hotkinson et al,. 2001. Strategic Management.

Hutabarat, Jemsly dan Martani Husaeni. 2006. Strategik di Tenganh Operasional Jakarta: Elex Media Computindo.

Ma'ruf , Hendri. 2006. Pemasaran Ritel. Jakarta: PT. Gramedia Pustaka.

Pearce dan Robinson. 1997. Strategic Management. Jakarta: Binarupa Aksara.

Porter, Michael. 1980. Competitive Strategy. New York The Free Press

Priyono, Edy, dkk. 2003. Analisis Cost Benefit Kehadiran Pengecer Besar. Final Report for Centre for Public Policy Analysis.

Scherer, F. M., \& Ross, D. 1990. Industrial Market Structure and Economic Performance. Boston: Houghton Mifflin Company

Sinaga, Pariaman. 2006. Dampak Keberadaan Pasar Modern 9Supermarket dan Hypermarket) terhadap Usaha Ritel Koperasi /WASREDA dan Pasar Tradisional. Jurnal Pengkajian Koperasi dan UKM No. Tahun 1. Bandung

Tambunan, Tulus, dkk. Kajian Persaingan Ritel . Penelitan KPPU. Jakarta

Umar, Husein. 2002. Strategic Managemen. Jakarta: Gramedia Pustaka.

Wirth, M. O., \& Bloch, H. 1995. Industrial organizati on theory and media industry analysis. The Journal of Media Economics. 8(2), 15-26.

Wheelen dan Hunger. 2001

Wahyudi, Agustinus. 1996. Manajemen Stratejik. Jakarta: Binarupa Aksara.

Harian Kompas. Sabtu 23 Juni 2007

Warta Ekonomi. 08 th. XIX 16 April 2007 